\title{
Analisis Kualitas Pelayanan dan Brand Image Terhadap Minat Kunjungan Ulang Pasien Klinik Bidan Marlina
}

\author{
Harun Al Rasyid ${ }^{1}$, Agus Tri Indah K ${ }^{2}$ \\ ${ }^{1}$ Universitas Bina Sarana Informatika \\ e-mail: harun.har@bsi.ac.id \\ ${ }^{2}$ Universitas Bina Sarana Informatika \\ e-mail: agus.ati@bsi.ac.id
}

\begin{abstract}
This study aimed to analyze the influence of service quality and brand image to re-visit interest. Samples were patients who were ambulatory and hospitalized at the Clinic Bidan Marlina Tangerang Selatan totaling 130 respondents. Regression analysis techniques were used to analyze the influence of service quality and brand image to re-visit interest is using SPSS (Statistical Package for the Social Sciences). Service quality and significant positive effect on the re-visit interest in Bidan Marlina Clinic Tangerang Selatan, every $1 \%$ increase in the variable quality of service will be followed by the increase in re-visit interest of 0.265 percent. While the brand image variable positive and significant effect on the interest re-visit the clinic Bidan Marlina Tangerang Selatan, every $1 \%$ increase in variable brand image will be followed by the increase in re-visit interest of 0.740 percent. Furthermore, the results also showed that there is a positive and significant influence on the independent variables of service quality and brand image together to re-visit interest. Service quality and brand image affects $65.7 \%$ of the interest to re-visit the clinic Bidan Marlina Tangerang Selatan.
\end{abstract}

Keywords: Quality Service, Brand Image, Revisit Interests, Clinic Bidan Marlina

\section{PENDAHULUAN}

Keberadaan fasilitas kesehatan masyarakat sebagai sarana pelayanan kesehatan memiliki peran yang sangat strategis khususnya dalam membantu memelihara kesehatan serta meningkatkan derajat kehidupan masyarakat. Semakin banyaknya fasilitas kesehatan yang berdiri dan tersebar di seluruh Indonesia merupakan bukti tingginya kebutuhan masyarakat akan fasilitas tersebut.

Fakta yang ada sekarang ini menunjukkan bahwa persaingan usaha telah meluas hingga ke jasa kesehatan, khususnya bisnis klinik kesehatan dan rumah sakit swasta. Saat ini hampir semua produk yang beredar di pasar memiliki produk kompetitor, demikian juga jasa kesehatan seperti klinik dan rumah sakit. Persaingan ketat telah mendorong klinik ataupun rumah sakit yang ada untuk mau tidak mau saling berlomba untuk menjadi yang terbaik, terutama klinik-klinik kesehatan dan rumah sakit swasta yang berada di kota besar.

Klinik Bidan Marlina merupakan salah satu klinik kesehatan dan persalinan yang ada di wilayah Tangerang Selatan. Klinik ini hadir guna menjawab tantangan atas kebutuhan masyarakat akan keberadaan sebuah klinik yang mampu melayani masyarakat 7 hari seminggu non stop. Klinik yang secara resmi berdiri pada tahun 1990 ini dilengkapi dengan obat-obatan dan fasilitas yang memadai, terutama yang bersifat emergensi. Lokasi klinik yang dikelilingi oleh lingkungan rumah padat penduduk kelas menengah dan menengah ke bawah, membuat klinik ini melakukan inovasi dengan membuat variasi harga yang sangat terjangkau sehingga membuat kehadiran klinik ini sangat berarti bagi masyarakat dan lingkungan sekitarnya.

Berdasarkan tipe pelayanannya, keberadaan klinik di Indonesia dibedakan menjadi 2 yaitu; Klinik Pratama dan Klinik Utama. Kedua macam klinik ini dapat diselenggarakan oleh pemerintah, pemerintah daerah ataupun masyarakat (swasta). Klinik Pratama merupakan klinik yang menyelenggarakan pelayanan medik dasar, sedangkan klinik utama merupakan klinik yang menyelenggarakan pelayanan medik spesialistik atau dibedakan atas pelayanan medik dasar dan spesialistik. Adapun pelayanan kesehatan yang diselenggarakan dapat berupa rawat jalan, one day care, rawat inap dan atau home care. Berdasarkan data dalam website bpjskesehatan.go.id tentang kerjasama Badan Penyelenggara Jaminan Sosial (BPJS) Kesehatan dengan fasilitas kesehatan bulan april 2016, paling tidak terdapat 3401 klinik pratama dan 104 klinik utama yang tersebar di seluruh Indonesia.

Meningkatnya jumlah klinik kesehatan dan rumah sakit dari waktu ke waktu menjadi tantangan bagi para pengelolanya, karena hal tersebut berdampak pada persaingan yang semakin ketat. Hanya klinik dan rumah sakit yang memiliki pelayanan yang berkualitas dan citra yang baiklah yang dapat bertahan dan unggul. Pengelola fasilitas kesehatan tersebut dituntut untuk mampu menyediakan pelayanan yang berkualitas dengan harga bersaing 
demi tercapainya kepuasan konsumen yang nantinya berdampak pada pembentukan brand image yang baik, sehingga akhirnya berefek pada timbulnya minat kunjungan ulang pasien.

\section{Minat Kunjungan Ulang}

(Parasuraman et al., 1998) menyatakan bahwa minat kunjungan ulang merupakan suatu keadaan untuk menggunakan kembali pelayanan disebabkan kepuasan terhadap pelayanan yang diperoleh sebelumnya. Adanya kepuasan terhadap pelayanan sebelumnya mendasari seseorang untuk kembali menggunakan suatu jasa atau produk tersebut dikemudian hari.

(Umar, 2003) mengungkapkan bahwa minat kunjungan ulang merupakan perilaku yang muncul sebagai respon terhadap objek yang menunjukkan keinginan pelanggan untuk melakukan pembelian ulang. Minat kunjungan ulang dapat juga diartikan sebagai bagian dari tahapan loyalitas konsumen seperti diungkapkan oleh (Oliver, 1997), beliau menyatakan bahwa loyalitas adalah komitmen pelanggan bertahan secara mendalam untuk berlangganan kembali atau melakukan tindakan pembelian ulang produk ataupun jasa terpilih secara konsisten dimasa yang akan datang, meskipun pengaruh situasi dan usaha-usaha pemasaran mempunyai potensi untuk menyebabkan perubahan perilaku.

Berdasarkan penjelasan di atas dapat disimpulkan bahwa minat kunjungan ulang atau loyalitas konsumen adalah respon terhadap objek yang menunjukkan keinginan konsumen untuk memilih penyedia layanan yang sama atau melakukan pembelian ulang produk atau jasa perusahaan yang sama di masa depan, dimana hal tersebut didasarkan atas pengalaman mereka sebelumnya.

Menurut Azwar dalam (Mahdani, 2009) indikator yang dapat memberi pengaruh kepada pasien dalam menentukan keputusannya terhadap penggunaan ulang pelayanan kesehatan antara lain :

1. Tersedia dan berkesinambungan

Syarat pokok pertama pelayanan yang baik adalah pelayanan kesehatan tersebut harus tersedia di masyarakat, serta bersifat berkesinambungan (sustainable). Artinya semua jenis pelayanan kesehatan yang dibutuhkan masyarakat tidak sulit ditemukan, serta keberadaannya dalam masyarakat adalah pada setiap saat dibutuhkan.

2. Dapat diterima dan wajar

Syarat pokok kedua pelayanan yang baik adalah yang dapat diterima oleh masyarakat (acceptable) serta bersifat wajar artinya pelayanan kesehatan tersebut tidak bertentangan dengan kenyakinan dan kepercayaan masyarakat. pelayanan kesehatan yang bertentangan dengan kenyakinan, adat istiadat, kebudayaan masyarakat serta bersifat tidak wajar bukanlah suatu keadaan pelayanan kesehatan yang baik.

3. Mudah di capai

Syarat pokok ke tiga adalah mudah dicapai (accessible) oleh masyarakat. Pengertian ketercapaian yang dimaksud disini terutama dari sudut lokasi. Dengan demikian untuk dapat mewujudkan pelayanan kesehatan yang baik maka pengaturan distribusi sarana kesehatan menjadi sangat penting. Bila fasilitas ini mudah dijangkau dengan menggunakan alat transportasi yang tersedia maka fasilitas ini akan banyak dipergunakan. Tingkat penggunaan dimasa lalu dan kecendrungan merupakan indikator terbaik untuk perubahan jangka panjang dan pendek dari permintaan pada masa yang akan datang.

4. Terjangkau

Syarat pokok keempat pelayanan yang baik adalah terjangkau (affordable) oleh masyarakat. Pengertian keterjangkauan yang dimaksud disini terutama dari sudut biaya untuk dapat mewujudkan harus dapat diupayakan biaya pelayanan kesehatan tersebut sesuai dengan kemampuan ekonomi masyarakat. Pelayanan kesehatan yang mahal yang hanya dapat dinikmati oleh sebahagian masyarakat saja, bukan pelayanan kesehatan yang baik.

5. Bermutu

Syarat pokok kelima pelayanan yang baik adalah bermutu (Quality) yaitu yang menunjukan pada tingkat kesempurnaan pelayanan kesehatan yang diselenggarakan, yang disatu pihak dapat memuaskan para pemakai jasa pelayanan dan dipihak lain tata cara penyelenggaraan sesuai kode etik serta standar yang telah ditetapkan.

\section{Kualitas Pelayanan}

Parasuraman dalam (Lupiyoadi, 2006) mendefinisikan kualitas pelayanan (Service Quality) sebagai seberapa jauh perbedaan antara harapan dan kenyataan para pelanggan atas layanan yang mereka terima atau peroleh.

Kualitas pelayanan menurut (Fandy Tjiptono, 2012) adalah upaya pemenuhan kebutuhan dan keinginan konsumen serta ketepatan penyampaiannya dalam mengimbangi harapan konsumen. Adapun kualitas pelayanan (Service Quality) dibangun atas adanya perbandingan dua faktor utama yaitu persepsi pelanggan atas layanan yang nyata mereka terima (perceived service) dengan layanan yang sesungguhnya diharapkan (F. Tjiptono \& Chandra, 2011).

Kualitas layanan mengacu pada penilaian-penilaian pelanggan tentang inti pelayanan, yaitu si pemberi pelayanan itu sendiri atau keseluruhan organisasi pelayanan, sebagian besar masyarakat sekarang mulai menampakkan tuntutan terhadap pelayanan 
prima, mereka bukan lagi sekedar membutuhkan produk yang bermutu tetapi mereka lebih senang menikmati kenyamanan pelayanan (Tasunar, 2006).

Berdasarkan pendapat para ahli di atas, dapat disimpulkan bahwa kualitas pelayanan adalah hasil penilaian pelanggan atas seberapa jauh perbedaan antara harapan dan kenyataan yang dirasakan dari suatu layanan yang mereka terima dari penyedia layanan (perusahaan), baik penilaian itu secara sebagian maupun secara keseluruhan. Apabila persepsi pelanggan atas layanan sesuai harapan maka kualitas layanan dianggap baik, namun jika persepsi pelanggan atas layanan tidak sesuai harapan maka kualitas layanan dianggap buruk. Oleh sebab itu, baik tidaknya kualitas layanan tergantung pada kemampuan penyedia layanan dalam memenuhi harapan pelanggannya secara konsisten.

Menurut Parasuraman, dkk dalam (Fandy Tjiptono, 2012) terdapat lima dimensi pokok untuk mengukur kualitas layanan. Dimensi pokok tersebut adalah :

1. Reliabilitas (Realibility), berkaitan dengan kemampuan perusahaan memberikan layanan yang disajikan secara akurat dan memuaskan.

2. Daya Tanggap (Responsiveness), berkenaan dengan kesediaan dan kemampuan penyedia layanan untuk membantu para pelanggan dan merespon permintaan mereka dengan segera.

3. Jaminan (Assurance), berkenaan dengan pengetahuan dan kesopanan karyawan serta kemampuan mereka dalam menumbuhkan rasa percaya (trust) dan keyakinan pelanggan (confidence).

4. Empati (Empathy), berarti bahwa perusahaan memahami masalah para pelanggannya dan bertindak demi kepentingan pelanggan, serta memberikan perhatian personal dan pemahaman atas kebutuhan individual para pelanggan tersebut.

5. Bukti Fisik (Tangibles), berkenaan dengan penampilan fisik fasilitas layanan, peralatan/ perlengkapan, sumber daya manusia, dan materi komunikasi perusahaan.

\section{Brand Image}

Menurut (Shimp, 2010) citra merek adalah asosiasi yang muncul dibenak konsumen ketika mengingat sebuah merek tertentu. Sedangkan pengertian citra merek menurut (Solihin, 2004) adalah merupakan segala sesuatu tentang merek suatu produk yang dipikirkan, dirasakan dan divisualisasikan oleh konsumen.

Menurut (Setiadi, 2008) citra merek mengacu pada skema memori akan sebuah merek, yang berisikan interpretasi konsumen atas atribut, kelebihan, penggunaan, situasi, para pengguna, dan karakteristik pemasar atau karakteristik pembuat dari produk atau merek tersebut. citra merek adalah apa yang konsumen pikirkan dan rasakan ketika mendengar atau melihat nama suatu merek.

Dari pendapat para ahli di atas dapat disimpulkan bahwa brand image atau citra merek merupakan persepsi atau asosiasi yang ada dalam ingatan konsumen atau apa yang mereka pikirkan dan rasakan atas merek suatu produk yang berasal dari interpretasi mereka atas atribut, kelebihan, penggunaan, situasi, para pengguna dan karakteristik pemasar atau karakteristik pembuat dari produk atau merek. Citra merek merupakan bentuk atau gambaran tertentu dari suatu jejak makna yang tertinggal di benak khalayak konsumen yang kemudian menuntun khalayak konsumen tersebut untuk bersikap terhadap merek.

Menurut Biel dalam (Xian, Xia, \& Yu, 2011) brand image memiliki tiga komponen pendukung, yaitu:

1. Citra pembuat (corporate / maker image) adalah sekumpulan asosiasi yang dipresepsikan konsumen terhadap perusahaan yang membuat suatu produk atau jasa.

2. Citra pemakai (user image) adalah sekumpulan asosiasi yang dipresepsikan konsumen terhadap pemakai yang menggunakan suatu barang atau jasa.

3. Citra produk (product image) adalah sekumpulan asosiasi yang dipresepsikan konsumen terhadap suatu produk.

\section{METODOLOGI PENELITIAN}

Metode penelitian merupakan suatu cara atau prosedur yang dipergunakan untuk melakukan penelitian, sehingga mampu menjawab rumusan masalah dan tujuan penelitian. Menurut (Sugiyono, 2012) Metode penelitian pada dasarnya merupakan cara ilmiah yang digunakan untuk mendapatkan data yang valid dengan tujuan dapat ditemukan, dikembangkan, dan dibuktikan, suatu pengetahuan tertentu sehingga pada gilirannya dapat digunakan untuk memahami, memecahkan, dan mengantisipasi masalah.

Adapun penelitian ini menggunakan pendekatan metode penelitian kuantitatif. Metode Penelitian Kuantitatif, sebagaimana dikemukakan oleh (Sugiyono, 2012) yaitu : Metode penelitian yang berlandaskan pada filsafat positivisme, digunakan untuk meneliti pada populasi atau sampel tertentu, pengumpulan data menggunakan instrumen penelitian, analisis data bersifat kuantitatif/statistik, dengan tujuan untuk menguji hipotesis yang telah ditetapkan.

Metode penelitian kuantitatif yang penulis gunakan dalam penelitian ini terdiri dari variabel terikat (dependen) dan varibel bebas (independen) yaitu berupa variabel Y sebagai variabel terikat dalam hal ini yang menjadi variabel $\mathrm{Y}$ adalah minat kunjungan ulang, sedangkan variabel $\mathrm{X} 1$ yaitu kualitas pelayanan sebagai variabel bebas, $\mathrm{X} 2$ yaitu brand 
image sebagai varibel bebas. Metode ini digunakan untuk mengetahui pengaruh kualitas pelayanan dan brand image terhadap minat kunjungan ulang.

Penelitian ini dilakukan di Klinik Bidan Marlina yang berada di wilayah Tangerang Selatan. Untuk obyek penelitiannya adalah para pasien klinik yang sedang berkunjung, baik untuk rawat jalan maupun rawat inap.

Data yang digunakan dalam penelitian ini adalah data primer, yaitu data yang diperoleh langsung dari penyebaran kuesioner di lokasi penelitian. Peneliti menggunakan kuesioner yang dibagikan kepada responden secara langsung, yaitu kepada para pasien yang sedang berkunjung untuk menjadi sampel dalam penelitian ini.

Menurut (Sanusi, 2011), populasi adalah seluruh kumpulan elemen yang menunjukkan ciri-ciri tertentu yang dapat digunakan untuk membuat kesimpulan. Jadi kumpulan elemen itu menunjukkan jumlah, sedangkan ciri-ciri tertentu menunjukkan karakteristik dari kumpulan itu. Sedangkan menurut (Sugiyono, 2012), populasi adalah wilayah generalisasi yang terdiri atas: obyek/subyek yang mempunyai kualitas dan karakteristik tertentu yang ditetapkan oleh peneliti untuk dipelajari dan kemudian ditarik kesimpulannya.

Jadi populasi bukan hanya orang, tetapi dapat juga obyek dan benda-benda alam yang lain. Populasi juga bukan sekedar yang ada pada obyek atau subyek yang dipelajari, akan tetapi meliputi seluruh karakteristik atau sifat yang dimiliki oleh subyek atau obyek yang diteliti itu. Pada penelitian ini populasinya adalah para pasien di Klinik Bidan Marlina yang sedang melakukan kunjungan baik rawat jalan maupun rawat inap.

Menurut (Sugiyono, 2012), sampel adalah bagian dari jumlah dan karakteristik yang dimiliki oleh populasi tersebut . Jadi, sampel adalah bagian dari populasi atau contoh. Bila populasi besar, dan peneliti tidak mungkin mempelajari semua yang ada pada populasi, misalnya karena keterbatasan dana, tenaga, dan waktu, maka peneliti dapat menggunakan sampel yang diambil dari populasi itu. Apa yang dipelajari dari sampel, kesimpulannya akan dapat diberlakukan untuk populasi. Untuk itu sampel yang diambil dari populasi harus betul-betul representatif (mewakili).

Teknik pengambilan sampel (sampling) adalah cara peneliti mengambil sampel atau contoh yang representatif dari populasi yang tersedia. Cara pengambilan sampel dari populasi juga dapat dilakukan dengan memperhatikan unsur berpeluang terpilih atau tidak terpilih sebagai sampel. Pengambilan sampel secara acak sederhana adalah proses memilih satuan sampling sedemikian rupa sehingga setiap satuan sampling dalam populasi mempunyai peluang yang sama untuk terpilih ke dalam sampel (Sanusi, 2011). Dalam penelitian ini, metode yang digunakan adalah simple random sampling, yakni pengambilan sampel dengan metode acak sederhana yang memungkinkan semua sampel memperoleh peluang yang sama. Jumlah sampel ditetapkan sebesar 130 orang dengan pertimbangan bahwa jumlah populasi memiliki jumlah yang sangat besar.

Pengambilan sampel sesuai dengan pendapat (Hair, JR, Anderson, Tatham, \& Black, 1998) bahwa untuk mendapatkan analisis statistik yang baik, jumlah sampel harus memenuhi sebanyak 4 sampai dengan 10 kali jumlah indikator kuesioner yang ditetapkan. Dengan jumlah indikator sebanyak 13 indikator, baik indikator pada variabel dependen (Y) dan variabel independen $(\mathrm{X} 1, \mathrm{X} 2)$ maka syarat minimal sampel yang harus diambil adalah sejumlah $10 \times 13$ $=130$ sampel.

Tahapan dalam penelitian ini adalah :

1. Merancang penelitian

Pada tahapan ini peneliti merumuskan bentuk penelitian yang akan dilakukan yaitu penelitian kuantitatif.

2. Menentukan populasi dan sampel

Pada tahapan ini peneliti menentukan populasi, adapun populasi dalam penelitian ini adalah para pasien yang berkunjung di Klinik Bidan Marlina baik untuk keperluan rawat jalan maupun rawat inap. Jumlah sampel yang akan diambil sebanyak 130 responden dengan menggunakan teknik pengambilan sampel random sampling. Pengambilan sampel dilakukan dengan cara menyebar kuesioner.

3. Menentukan model penelitian

Pada tahapan ini model penelitian yang akan dipakai yaitu model penelitian dengan analisis regresi linear berganda.

4. Mendefinisikan variabel dan indikator penelitian Pada tahapan ini peneliti menentukan variabel variabel yang akan digunakan dalam penelitian ini adalah KP (Kualitas Pelayanan) dan BI (Brand Image) sebagai variabel bebas, serta variabel tidak bebas (terikat) adalah MKU (Minat Kunjungan Ulang). Kemudian menentukan indikator dari variabel bebas dan terikat yang akan digunakan dalam kuesioner.

5. Kuesioner

Pada tahapan ini peneliti membuat kuesioner berdasarkan indikator yang sudah ditentukan sebelumnya. Kemudian disebarkan kepada responden untuk diisi sehingga mendapatkan informasi yang dibutuhkan. Responden dalam penelitian ini adalah para pasien Klinik Bidan Marlina yang sedang melakukan kunjungan baik rawat jalan maupun rawat inap.

6. Pengumpulan Data

Pada tahapan ini adalah penyebaran serta pengumpulan kuesioner dari para responden yang terpilih.

7. Menganalisa data

Dari kuesioner yang telah disebarkan serta sudah 
di isi oleh responden, dikumpulkan kembali oleh peneliti untuk analisa data.

8. Analisis regresi linear berganda dengan SPSS Pada tahapan ini peneliti melakukan analisa data dengan menggunakan software SPSS 20.

9. Menarik kesimpulan

Pada tahapan penelitian ini setelah dilakukan analisa data dengan SPSS 20 maka ditarik kesimpulan dari permasalahan yang diteliti.

\section{Kerangka Berpikir}

Berdasarkan kajian teori diatas, penulis merumuskan kerangka berfikir sebagai berikut :

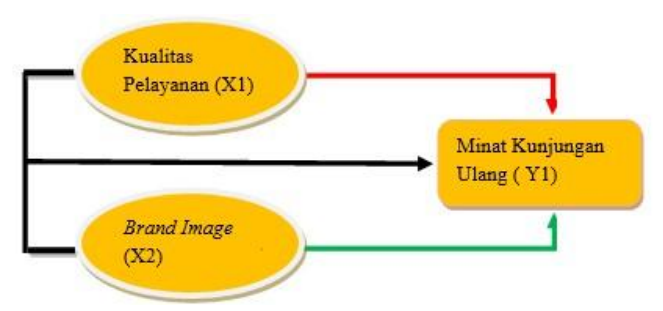

Gambar 1. Kerangka Berpikir

Hipotesis

1. $\mathrm{H}_{0}$ : Tidak terdapat pengaruh variabel kualitas pelayanan $\left(\mathrm{X}_{1}\right)$ terhadap minat kunjungan ulang $\left(\mathrm{Y}_{1}\right)$.

$\mathrm{H}_{1}$ : Terdapat pengaruh variabel kualitas pelayanan $\left(\mathrm{X}_{1}\right)$ terhadap minat kunjungan ulang $\left(\mathrm{Y}_{1}\right)$.

2. $\mathrm{H}_{0}$ : Tidak terdapat pengaruh variabel brand image $\left(\mathrm{X}_{2}\right)$ terhadap minat kunjungan ulang $\left(\mathrm{Y}_{1}\right)$.

$\mathrm{H}_{1}$ : Terdapat pengaruh variabel brand image $\left(\mathrm{X}_{2}\right)$ terhadap minat kunjungan ulang $\left(\mathrm{Y}_{1}\right)$.

3. H0 : Tidak terdapat pengaruh variabel kualitas pelayanan (X1) dan brand image (X2) secara serempak terhadap minat kunjungan ulang (Y1).

H1 : Terdapat pengaruh variabel kualitas pelayanan (X1) dan brand image (X2) secara serempak terhadap minat kunjungan ulang (Y1).

\section{HASIL DAN PEMBAHASAN \\ Karakteristik Responden}

Hasil penelitian dengan menyebar kuesioner kepada 130 pasien di Klinik Bidan Marlina yang berada di wilayah kawasan tangerang selatan. Didapatkan hasil bahwa responden dalam penelitian lebih didominasi oleh wanita yakni sebesar 82,31 persen, sedangkan responden dengan jenis kelamin pria hanya sebesar 17,69 persen. Hal ini dapat disebabkan pasien di klinik bidan marlina didominasi oleh wanita yang memeriksakan kehamilan, kandungan dan akan melakukan persalinan. Kemudian didapatkan hasil bahwa responden dalam penelitian pada setiap segmen usia hampir tersebar merata, yang paling banyak berusia diantara 31-35 tahun yakni sebesar 23,8 persen, kemudian 26-30 tahun yakni sebesar 21,5 persen, dan diantara 36-40 tahun sebesar 13,8 persen. Kecenderungan responden yang cukup dewasa dan berusia produktif dapat disebabkan rata-rata responden memeriksakan diri ke poli kandungan yang umumnya pada usia dewasa dan masih produktif. Selanjutnya didapatkan juga bahwa responden dalam penelitian sebagian besar berstatus sebagai ibu rumah tangga yakni sebesar 41,5 persen, responden yang berprofesi sebagai karyawan swasta sebesar 33,8 persen.Lokasi riset diklinik yang didominasi oleh kunjungan pada poli kandungan membuat responden lebih didominasi oleh ibu rumah tangga. Kemudian dalam hal pendidikan diketahui bahwa responden dalam penelitian ini sebagian besar berpendidikan SMA Sederajat, yakni mencapai 50 persen, kemudian S1/S2 sebesar 21,5 persen dan Diploma sebesar 16,2 persen. Pendidikan responden yang secara umum sudah tinggi membuat responden mudah memahami pernyataan yang diberikan.

\section{Uji Validitas dan Reliabilitas}

Adapun untuk indikator-indikator setiap variabel untuk uji validitas dan realibilitas adalah sebagai berikut:

Tabel 1. Dimensi, Indikator dan Nomor Butir Kuesioner Kualitas Pelayanan

\begin{tabular}{|c|c|c|c|}
\hline Variabel & Dimensi & Indikator & $\begin{array}{l}\text { Nomor } \\
\text { butir }\end{array}$ \\
\hline \multirow{15}{*}{$\begin{array}{l}\text { Kualitas } \\
\text { Pelayanan }\end{array}$} & \multirow{3}{*}{$\begin{array}{l}\text { Keandalan } \\
\text { (realibility) }\end{array}$} & $\begin{array}{l}\text { Kemudahan } \\
\text { pelayanan }\end{array}$ & 1 \\
\hline & & $\begin{array}{l}\text { Kesesuaian } \\
\text { jadwal kerja }\end{array}$ & 2 \\
\hline & & $\begin{array}{l}\text { Pelayanan yang } \\
\text { tepat }\end{array}$ & 3 \\
\hline & \multirow{3}{*}{$\begin{array}{c}\text { b. Daya tanggap } \\
\text { (responsivenes } \\
s \text { ) }\end{array}$} & $\begin{array}{l}\text { Respon } \\
\text { pelayanan }\end{array}$ & 4 \\
\hline & & $\begin{array}{l}\text { Daya tanggap } \\
\text { atas kebutuhan }\end{array}$ & 5 \\
\hline & & $\begin{array}{l}\text { Reaksi tanggap } \\
\text { pelayanan }\end{array}$ & 6 \\
\hline & \multirow{3}{*}{$\begin{array}{l}\text { c. Jaminan } \\
\text { (assurance) }\end{array}$} & $\begin{array}{l}\text { Kejelasan atas } \\
\text { informasi }\end{array}$ & 7 \\
\hline & & $\begin{array}{l}\text { Meyakinkan } \\
\text { akan tindakan }\end{array}$ & 8 \\
\hline & & $\begin{array}{l}\text { Keamanan dan } \\
\text { kenyamanan } \\
\text { tindakan }\end{array}$ & 9 \\
\hline & \multirow{3}{*}{$\begin{array}{l}\text { d. Empati } \\
\text { (empathy) }\end{array}$} & $\begin{array}{l}\text { Memberi } \\
\text { perhatian lebih }\end{array}$ & 10 \\
\hline & & $\begin{array}{l}\text { Mendengar } \\
\text { keluhan } \\
\text { seksama }\end{array}$ & 11 \\
\hline & & $\begin{array}{l}\text { Pelayanan tanpa } \\
\text { membedakan }\end{array}$ & 12 \\
\hline & \multirow{3}{*}{$\begin{array}{l}\text { e. Bukti fisik } \\
\text { (Tangibles) }\end{array}$} & $\begin{array}{l}\text { Kebersihan } \\
\text { lingkungan }\end{array}$ & 13 \\
\hline & & $\begin{array}{l}\text { Kenyamanan } \\
\text { tempat }\end{array}$ & 14 \\
\hline & & $\begin{array}{l}\text { Kerapian dan } \\
\text { disiplin }\end{array}$ & 15 \\
\hline
\end{tabular}

Sumber: (Fandy Tjiptono, 2012)

Tabel 2. Dimensi, Indikator dan Nomor Butir Kuesioner Brand Image

\begin{tabular}{cclc}
\hline Variabel & Dimensi & Indikator & $\begin{array}{c}\text { Nomor } \\
\text { butir }\end{array}$ \\
\hline & a. Citra pembuat & $\begin{array}{l}\text { Reputasi yang } \\
\text { baik }\end{array}$ & 16 \\
\cline { 3 - 4 } $\begin{array}{c}\text { Image } \\
\text { (corporate / maker } \\
\text { image) }\end{array}$ & $\begin{array}{l}\text { Pelayanan } \\
\text { yang tersebar } \\
\text { luas }\end{array}$ & 17 \\
\hline
\end{tabular}




\begin{tabular}{clll}
\hline \multirow{2}{*}{$\begin{array}{c}\text { b. Citra pemakai } \\
\text { (user image) }\end{array}$} & $\begin{array}{l}\text { Status } \\
\text { pengunjung }\end{array}$ & 18 \\
\cline { 2 - 3 } & $\begin{array}{l}\text { Keamanan } \\
\text { atas pelayanan }\end{array}$ & 19 \\
\cline { 2 - 3 } $\begin{array}{c}\text { c. Citra produk } \\
\text { (produk image) }\end{array}$ & \begin{tabular}{l} 
Mudah diingat \\
\cline { 2 - 3 }
\end{tabular} & $\begin{array}{l}\text { Tawaran jasa } \\
\text { layanan }\end{array}$ & 20 \\
\hline
\end{tabular}

Sumber : (Xian et al., 2011)

Tabel 3. Dimensi, Indikator dan Nomor Butir Kuesioner Minat Kunjungan Ulang

\begin{tabular}{|c|c|c|c|}
\hline Variabel & Dimensi & Indikator & $\begin{array}{c}\begin{array}{c}\text { Nomor } \\
\text { butir }\end{array} \\
\end{array}$ \\
\hline \multirow{9}{*}{$\begin{array}{c}\text { Minat } \\
\text { Kunjungan } \\
\text { Ulang }\end{array}$} & \multirow{2}{*}{$\begin{array}{c}\text { a. Tersedia dan } \\
\text { berkesinambungan } \\
\quad(\text { sustainable })\end{array}$} & $\begin{array}{c}\text { Pelayanan } \\
\text { khusus }\end{array}$ & 22 \\
\hline & & $\begin{array}{c}\text { Kelengkapan } \\
\text { sarana }\end{array}$ & 23 \\
\hline & \multirow{2}{*}{$\begin{array}{c}\text { b. Dapat diterima } \\
\text { dan wajar } \\
\text { (acceptable })\end{array}$} & $\begin{array}{c}\text { Standar } \\
\text { ketetapan } \\
\text { pelayanan }\end{array}$ & 24 \\
\hline & & $\begin{array}{c}\text { Kesesuaian } \\
\text { aturan }\end{array}$ & 25 \\
\hline & \multirow{2}{*}{$\begin{array}{l}\text { c. Mudah dicapai } \\
\text { (accessible) }\end{array}$} & $\begin{array}{c}\text { Kemudahan } \\
\text { akses }\end{array}$ & 26 \\
\hline & & $\begin{array}{c}\text { Keterjangkauan } \\
\text { jarak }\end{array}$ & 27 \\
\hline & \multirow{2}{*}{$\begin{array}{l}\text { d. Terjangkau } \\
\text { (affordable) }\end{array}$} & $\begin{array}{c}\text { Keterjangkauan } \\
\text { harga perawatan } \\
\text { jalan }\end{array}$ & 28 \\
\hline & & $\begin{array}{c}\text { Keterjangkauan } \\
\text { harga perawatan } \\
\text { inap }\end{array}$ & 29 \\
\hline & $\begin{array}{l}\text { e. Bermutu } \\
\text { (Quality) }\end{array}$ & $\begin{array}{c}\text { Kepuasan } \\
\text { layanan secara } \\
\text { keseluruhan }\end{array}$ & 30 \\
\hline
\end{tabular}

Sumber: (Mahdani, 2009)

Hasil uji validitas dan reliabilitas pada item kuesioner penelitian yang diuji pada 30 responden awal dapat dilihat pada tabel berikut:

Tabel 4. Hasil Uji Validitas

\begin{tabular}{lllll}
\hline Variabel & Item Pertanyaan & r hitung & r tabel & Ket \\
\hline & Kualitas Pelayanan 1 & $0,551^{* *}$ & 0,361 & Valid \\
\cline { 2 - 5 } & Kualitas Pelayanan 2 & $0,431^{*}$ & 0,361 & Valid \\
\cline { 2 - 5 } & Kualitas Pelayanan 3 & $0,587^{* *}$ & 0,361 & Valid \\
\cline { 2 - 5 } & Kualitas Pelayanan 4 & $0,490^{* *}$ & 0,361 & Valid \\
\cline { 2 - 5 } Kualitas & Kualitas Pelayanan 5 & $0,621^{* *}$ & 0,361 & Valid \\
\cline { 2 - 5 } Pelayanan & Kualitas Pelayanan 6 & $0,588^{* *}$ & 0,361 & Valid \\
\cline { 2 - 5 } & Kualitas Pelayanan 7 & $0,645^{* *}$ & 0,361 & Valid \\
\cline { 2 - 5 } & Kualitas Pelayanan 8 & $0,721^{* *}$ & 0,361 & Valid \\
\cline { 2 - 5 } & Kualitas Pelayanan 9 & $0,700^{* * *}$ & 0,361 & Valid \\
\cline { 2 - 5 } & Kualitas Pelayanan 10 & $0,546^{* *}$ & 0,361 & Valid \\
\cline { 2 - 5 } & Kualitas Pelayanan 11 & $0,560^{* *}$ & 0,361 & Valid \\
\cline { 2 - 5 } & Kualitas Pelayanan 12 & $0,415^{* *}$ & 0,361 & Valid \\
\cline { 2 - 5 } & Kualitas Pelayanan 13 & $0,644^{* *}$ & 0,361 & Valid \\
\hline
\end{tabular}

\begin{tabular}{|c|c|c|c|c|}
\hline & Kualitas Pelayanan 14 & $0,494^{* *}$ & 0,361 & Valid \\
\hline & Kualitas Pelayanan 15 & $0,444^{*}$ & 0,361 & Valid \\
\hline Variabel & Item Pertanyaan & r hitung & $\mathbf{r}$ tabel & Ket \\
\hline \multirow{6}{*}{$\begin{array}{l}\text { Brand } \\
\text { Image }\end{array}$} & Brand Image 1 & $0,825^{* *}$ & 0,361 & Valid \\
\hline & Brand Image 2 & $0,643^{* * *}$ & 0,361 & Valid \\
\hline & Brand Image 3 & $0,789^{* * *}$ & 0,361 & Valid \\
\hline & Brand Image 4 & $0,655^{* *}$ & 0,361 & Valid \\
\hline & Brand Image 5 & $0,838^{* *}$ & 0,361 & Valid \\
\hline & Brand Image 6 & $0,805^{* *}$ & 0,361 & Valid \\
\hline Variabel & Item Pertanyaan & r hitung & $\mathbf{r}$ tabel & Ket \\
\hline \multirow{9}{*}{$\begin{array}{l}\text { Minat } \\
\text { Kunjungan } \\
\text { Ulang }\end{array}$} & Minat Kunjungan Ulang 1 & $0,721^{* *}$ & 0,361 & Valid \\
\hline & Minat Kunjungan Ulang 2 & $0,614^{* *}$ & 0,361 & Valid \\
\hline & Minat Kunjungan Ulang 3 & $0,648^{* *}$ & 0,361 & Valid \\
\hline & Minat Kunjungan Ulang 4 & $0,587^{* *}$ & 0,361 & Valid \\
\hline & Minat Kunjungan Ulang 5 & $0,654^{* *}$ & 0,361 & Valid \\
\hline & Minat Kunjungan Ulang 6 & $0,661^{* *}$ & 0,361 & Valid \\
\hline & Minat Kunjungan Ulang 7 & $0,600^{* * *}$ & 0,361 & Valid \\
\hline & Minat Kunjungan Ulang 8 & $0,656^{* *}$ & 0,361 & Valid \\
\hline & Minat Kunjungan Ulang 9 & $0,714^{* *}$ & 0,361 & Valid \\
\hline
\end{tabular}

Sumber : Hasil pengolahan data (2018)

Berdasarkan hasil pengolahan data pada tabel diatas, item pertanyaan pada setiap variabel semuanya valid, sebab nilai $\mathrm{r}$ hitung lebih besar dari nilai $\mathrm{r}$ tabel $(\mathrm{r}$ hitung $>r$ tabel).

\begin{tabular}{lllll}
\hline No & Variabel & $\begin{array}{l}\text { Cronbach } \\
\text { Alpha }\end{array}$ & Standar & Ket \\
\hline 1 & $\begin{array}{l}\text { Kualitas } \\
\text { Pelayanan }\end{array}$ & 0,833 & 0.600 & Reliabel \\
\hline 2 & Brand Image & 0,841 & 0.600 & Reliabel \\
\hline 3 & $\begin{array}{l}\text { Minat } \\
\text { Kunjungan } \\
\text { Ulang }\end{array}$ & 0,823 & 0.600 & Reliabel \\
\hline
\end{tabular}

Sumber : Hasil pengolahan data (2018)

Berdasarkan hasil pengolahan data, semua variabel dalam penelitian ini reliabel, hal itu dapat dilihat dari nilai cronbach alpha pada semua variabel lebih besar dari nilai standar.

\section{Uji Asumsi Klasik}

\section{1). Uji Normalitas Data}

Uji normalitas data bertujuan untuk menguji apakah dalam model regresi, variabel pengganggu atau residual memiliki distribusi normal. Uji ini dilakukan dengan bantuan program for society science (SPSS) metode normal probability plot $(N P P)$.

Metode normal probability plot (NPP) dilakukan dengan cara membandingkan data riil dengan data distribusi normal (otomatis dengan computer) secara komulatif. Suatu data dikatakan berdistribusi normal jika garis data mengikuti garis normal. 
Untuk menguji apakah dalam model regresi, variabel dependen (terikat) dan variabel independen (bebas) keduanya mempunyai distribusi normal dapat dilihat pada grafik Histogram maupun grafik normal P-P Plot. Distribusi data haruslah normal atau mendekati normal untuk memenuhi asumsi normalitas.

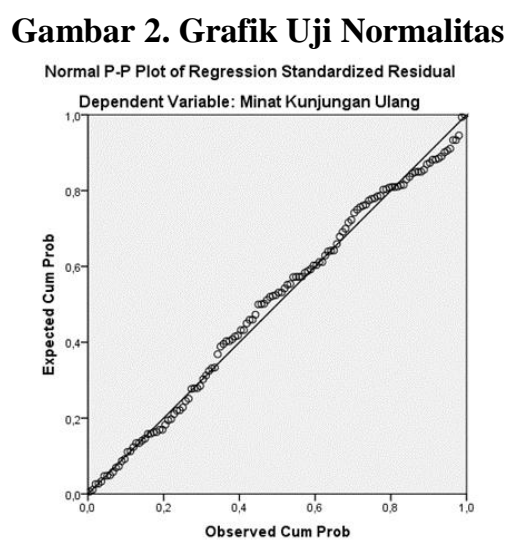

Sumber : Hasil pengolahan data (2018)

Gambar 2 adalah diagram yang menggambarkan plot antara nilai residu (ZRESID) dengan nilai prediksi (ZPRED) pada regresi jalur kedua (berganda) yang dengannya dapat terlihat normalitas sebuah model regresi berganda, pada penelitian ini, model telah normal karena nilai residu yang mengikuti alur residu normal seperti pada gambar tersebut.

\section{2). Uji Heterokedastisitas}

Uji heteroskedastisitas adalah untuk melihat apakah terdapat ketidaksamaan varians dari residual satu ke pengamatan ke pengamatan yang lain. Model regresi yang memenuhi persyaratan adalah di mana terdapat kesamaan varians dari residual satu pengamatan ke pengamatan yang lain tetap atau disebut homoskedastisitas. Deteksi heteroskedastisitas dapat dilakukan dengan metode scatter plot dengan memplotkan nilai ZPRED (nilai prediksi) dengan ZRESID (nilai residualnya). Model yang baik didapatkan jika tidak terdapat pola tertentu pada grafik, seperti mengumpul di tengah, menyempit kemudian melebar atau sebaliknya melebar kemudian menyempit. Oleh karena itu berdasarkan Gambar berikut:

\section{Gambar 3 Grafik Uji Heterokedastisitas}

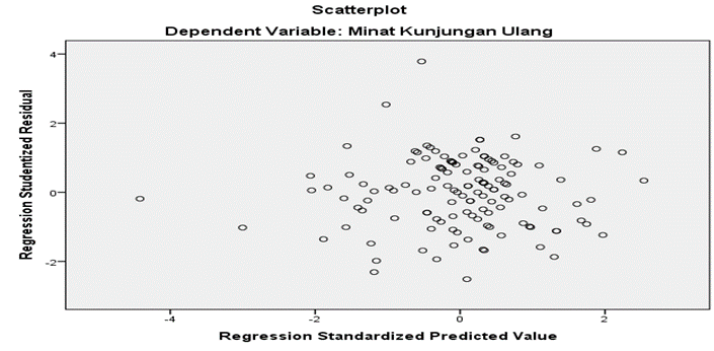

Sumber : Hasil pengolahan data (2018)
Berdasarkan Gambar 3 terlihat bahwa dengan memplotkan nilai ZPRED (nilai prediksi) dengan ZRESID (nilai residualnya). Model yang didapatkan tidak terdapat pola tertentu pada grafik, sehingga model terbebas dari masalah heterokedastisitas.

\section{3). Uji Multikolinieritas}

Uji Multikolinieritas bertujuan untuk menguji apakah pada model regresi ditemukan adanya hubungan yang kuat diantara variabel independen. (Ghozali, 2006) mengemukakan nilai cut-off yang umum dipakai untuk menunjukan adanya multikolinearitas adalah nilai tolerance $\leq 0,10$ atau sama dengan nilai VIF (Variance Inflation Factor) $\geq 10$.

Tabel 6. Uji Multikolinieritas

\begin{tabular}{lll}
\hline Variabel & VIF & Keterangan \\
\hline $\mathrm{X} 1$ & 1,595 & Non Multikolinieritas \\
\hline $\mathrm{X} 2$ & 1,595 & Non Multikolinieritas \\
\hline \multicolumn{2}{c}{ Sumber } & Hasil pengolahan data (2018)
\end{tabular}

Berdasarkan Tabel 6 diketahui bahwa diantara variabel-variabel bebas yang digunakan mempunyai nilai VIF lebih kecil dari 10, dari hasil tersebut dapat disimpulkan bahwa model regresi linier tersebut bebas dari multikolinearitas atau tidak terjadi korelasi diantara satu dengan yang lain.

\section{Pengujian Hipotesis}

\section{1). Uji Regresi Linier Berganda}

Perhitungan regresi linier berganda digunakan untuk memprediksi besarnya hubungan antara variabel terikat (dependen) yaitu Minat Kunjungan Ulang (Y), dengan variabel bebas (independen) yaitu Kualitas Pelayanan $\left(\mathrm{X}_{1}\right)$, dan Brand Image $\left(\mathrm{X}_{2}\right)$, Hasil regresi linier berganda dapat dilihat dibawah ini :

Tabel 7

Hasil Uji Regresi Berganda Coefficients $^{\mathrm{a}}$

\begin{tabular}{|c|c|c|c|c|c|c|}
\hline \multicolumn{7}{|c|}{ Coefficients $^{a}$} \\
\hline & \multirow[t]{2}{*}{ Model } & \multicolumn{2}{|c|}{$\begin{array}{l}\text { Unstandardized } \\
\text { Coefficients }\end{array}$} & \multirow{2}{*}{$\begin{array}{c}\text { Standard } \\
\text { ized } \\
\text { Coefficie } \\
\text { nts } \\
\text { Beta }\end{array}$} & \multirow[t]{2}{*}{$t$} & \multirow[t]{2}{*}{ Sig. } \\
\hline & & B & $\begin{array}{l}\text { Std. } \\
\text { Error }\end{array}$ & & & \\
\hline \multirow{3}{*}{1} & (Constant) & 1,618 & 2,118 & & ,764 & ,446 \\
\hline & $\begin{array}{l}\text { Kualitas } \\
\text { Pelayanan }\end{array}$ & 265 & ,042 & ,411 & 6,252 & ,000 \\
\hline & Brand Image & ,740 & ,099 & ,492 & 7,485 &, 000 \\
\hline
\end{tabular}

a. Dependent Variable: Minat Kunjungan Ulang

Sumber : Hasil pengolahan data (2018)

Berdasarkan tabel 7 diketahui bahwa nilai konstanta a yang diperoleh sebesar 1,618 , koefisien arah regresi $\mathrm{b}_{1}$ sebesar 0,265, dan koefisien arah regresi $\mathrm{b}_{2}$ sebesar 0,740. Dan dari hasil pengolahan data diperoleh koefisien regresi dari tabel diatas sebagai berikut : $\hat{\mathbf{Y}}$ $=1,618+0,265\left(X_{1}\right)+0,740\left(X_{2}\right)$

Dari hasil persamaan regresi linier berganda diatas maka dapat diketahui bahwa :

a. Nilai konstanta 1,618, artinya jika Kualitas 
Pelayanan $\left(\mathrm{X}_{1}\right)$, dan Brand Image $\left(\mathrm{X}_{2}\right)$ bernilai nol, maka nilai Minat Kunjungan Ulang(Y) 1,618 .

b. Koefisien regresi variabel Kualitas Pelayanan $\left(\mathrm{X}_{1}\right)$ menunjukan nilai positif yaitu 0,265 . Hal ini menunjukan bahwa variabel Kualitas Pelayanan $\left(\mathrm{X}_{1}\right)$ berpengaruh positif terhadap peningkatan Minat Kunjungan Ulang(Y), artinya semakin tinggi tingkat Kualitas Pelayanan $\left(\mathrm{X}_{1}\right)$ akan menyebabkan semakin meningkatnya pula Minat Kunjungan Ulang(Y).

c. Koefisien regresi variabel Brand Image $\left(\mathrm{X}_{2}\right)$ menunjukan nilai positif yaitu 0,740 . Hal ini menunjukan bahwa variabel Brand Image $\left(\mathrm{X}_{2}\right)$ berpengaruh positif terhadap peningkatan Minat Kunjungan Ulang(Y), artinya semakin tinggi tingkat Brand Image $\left(\mathrm{X}_{2}\right)$ akan menyebabkan semakin tinggi pengaruhnya terhadap Minat Kunjungan Ulang(Y).

\section{2). Uji Hipotesis t (Uji t)}

Pengujian hipotesis ini untuk mengetahui apakah variabel independen berpengaruh sendiri-sendiri terhadap variabel terikat dan variabel independen (bebas) manakah yang paling dominan pengaruhnya terhadap Minat Kunjungan Ulang.

\section{Pengaruh Kualitas Pelayanan terhadap Minat Kunjungan Ulang (Y)}

Pembuktian hipotesis pengaruh Kualitas Pelayanan terhadap Minat Kunjungan Ulang dapat ditulis sebagai berikut :

H0 : tidak terdapat pengaruh yang signifikan Kualitas Pelayanan terhadap Minat Kunjungan Ulang

H1 : terdapat pengaruh yang signifikan Kualitas Pelayanan terhadap Minat Kunjungan Ulang.

Menurut ketentuan yang ada, kriteria signifikansi regresi tersebut adalah "jika $t_{\text {hitung }}>t_{\text {tabel }}$ maka $\mathrm{H} 0$ ditolak" atau "jika Sig < 0,05 maka H0 ditolak", yang berarti bahwa terdapat pengarsuh yang signifikan variabel bebas $\mathrm{X}_{1}$ terhadap variabel terikat Y.

Dari hasil Uji t dari tabel 4.14 menujukkan bahwa variabel independen Kualitas Pelayanan $\left(\mathrm{X}_{1}\right)$ mempunyai pengaruh yang signifikan terhadap variabel dependen Minat Kunjungan Ulang(Y) sebab variabel Kualitas Pelayanan $\left(\mathrm{X}_{1}\right)$ memiliki nilai signifikansi 0,000. Nilai Sig t $<5 \%(0,000<0,05)$. Dengan demikian pengujian Ho ditolak dan $\mathrm{Ha}$ diterima. Hal ini memperlihatkan bahwa Kualitas Pelayanan $\left(X_{1}\right)$ berpengaruh signifikan terhadap Minat Kunjungan Ulang (Y). Adapun besarnya pengaruh adalah sebesar 0,411 .

\section{Pengaruh Brand Image terhadap Minat}

\section{Kunjungan Ulang (Y)}

Pembuktian hipotesis pengaruh Brand Image terhadap
Minat Kunjungan Ulang dapat ditulis sebagai berikut: $\mathrm{HO}$ : tidak terdapat pengaruh yang signifikan Brand Image terhadap Minat Kunjungan Ulang

H1 : terdapat pengaruh yang signifikan Brand Image terhadap Minat Kunjungan Ulang.

Menurut ketentuan yang ada, kriteria signifikansi regresi tersebut adalah "jika $t_{\text {hitung }}>\mathrm{t}_{\text {tabel }}$ maka $\mathrm{H} 0$ ditolak" atau "jika Sig < 0,05 maka H0 ditolak", yang berarti bahwa terdapat pengarsuh yang signifikan variabel bebas $\mathrm{X}_{2}$ terhadap variabel terikat $\mathrm{Y}$.

Dari hasil Uji t dari tabel 4.14 menujukkan bahwa variabel independen Brand Image $\left(\mathrm{X}_{2}\right)$ mempunyai pengaruh yang signifikan terhadap variabel dependen Minat Kunjungan Ulang (Y) sebab variabel Brand Image $\left(\mathrm{X}_{2}\right)$ memiliki nilai signifikansi 0,000 . Nilai Sig $\mathrm{t}<5 \%(0,000<0,05)$. Dengan demikian pengujian Ho ditolak dan $\mathrm{Ha}$ diterima. Hal ini memperlihatkan bahwa Brand Image $\left(\mathrm{X}_{2}\right)$ berpengaruh signifikan terhadap Minat Kunjungan Ulang (Y). Adapun besarnya pengaruh adalah sebesar 0,492 .

\section{3). Uji Hipotesis F (Uji F)}

Pengujian hipotesis ini yaitu untuk mengetahui pengaruh antara seluruh variabel independen (bebas) dengan variabel dependen (terikat). Hipotesis persamaan regresi berganda dalam penelitian ini adalah :

H0 : tidak terdapat pengaruh yang signifikan Kualitas Pelayanan dan Brand Image secara bersamasama terhadap Minat Kunjungan Ulang .

H1 : terdapat pengaruh yang signifikan Kualitas Pelayanan dan Brand Image secara bersamasama terhadap Minat Kunjungan Ulang .

Hasil pengujian hipotesis $\mathrm{F}$ dapat dilihat pada tabel berikut:

\section{Tabel 8}

\begin{tabular}{|c|c|c|c|c|c|c|}
\hline \multicolumn{4}{|c|}{ Hasil Uji F (Anova) } & \multicolumn{3}{|c|}{ ANOVA $^{a}$} \\
\hline & Model & $\begin{array}{c}\text { Sum of } \\
\text { Squares }\end{array}$ & $\mathrm{df}$ & $\begin{array}{l}\text { Mean } \\
\text { Square }\end{array}$ & $\mathrm{F}$ & Sig. \\
\hline \multirow{3}{*}{1} & Regression & 1628,352 & 2 & 814,176 & 121,482 &, $000^{b}$ \\
\hline & Residual & 851,155 & 127 & 6,702 & & \\
\hline & Total & 2479,508 & 129 & & & \\
\hline
\end{tabular}

a. Dependent Variable: Minat Kunjungan Ulang

b. Predictors: (Constant), Brand Image, Kualitas Pelayanan Sumber : Hasil pengolahan data (2018)

Berdasarkan hasil perhitungan yang dapat dilihat pada tabel 4.15, menunjukkan Signifikansi $F=0.000$. Jadi Sig F $<5 \%(0.000<0.05)$, dengan demikian Ha diterima dan Ho ditolak yang berarti bahwa secara serempak variabel $\mathrm{X}_{1}, \mathrm{X}_{2}$ mempunyai pengaruh yang signifikan terhadap variabel Y. Jadi terbukti bahwa variabel Kualitas Pelayanan $\left(\mathrm{X}_{1}\right)$ dan variabel Brand Image $\left(X_{2}\right)$ berpengaruh secara bersama-sama terhadap Minat Kunjungan Ulang.

\section{4). Koefisien Determinasi $\left(\mathbf{R}^{2}\right)$}

Koefisien determinasi berganda $\left(\mathrm{R}^{2}\right)$ digunakan untuk mengetahui besarnya sumbangan atau 
kontribusi dari keseluruhan variabel bebas pengaruhnya terhadap variabel terikat $(\mathrm{Y})$, sedangkan sisanya dipengaruhi oleh variabel lain yang tidak dimasukkan dalam model. Hasil koefisien determinasi dapat dilihat pada tabel berikut :

\section{Tabel 9}

Hasil Koefisien Determinasi (Model Summary)

\begin{tabular}{|c|c|c|c|c|c|}
\hline \multicolumn{6}{|c|}{ Model Summary } \\
\hline Model & $\mathrm{R}$ & $\begin{array}{c}\mathrm{R} \\
\text { Square }\end{array}$ & $\begin{array}{l}\text { Adjusted } \\
\text { R Square }\end{array}$ & $\begin{array}{l}\text { Std. Error } \\
\text { of the } \\
\text { Estimate }\end{array}$ & $\begin{array}{l}\text { Durbin- } \\
\text { Watson }\end{array}$ \\
\hline 1 & $810^{\mathrm{a}}$ & 657 & .651 & 2,58882 & 2,263 \\
\hline
\end{tabular}

a. Predictors: (Constant), Brand Image, Kualitas Pelayanan

b. Dependent Variable: Minat Kunjungan Ulang

Sumber : Hasil pengolahan data (2018)

Berdasarkan Tabel 9 dapat diketahui bahwa koefisien determinasi $\left(\mathrm{R}^{2}\right)$ sebesar 0,657 atau $65,7 \%$. Artinya variabel $\mathrm{Y}$ dijelaskan sebesar $65,7 \%$ oleh variabel Kualitas Pelayanan $\left(\mathrm{X}_{1}\right)$ dan variabel Brand Image $\left(\mathrm{X}_{2}\right)$ sedangkan sisanya sebesar $34,3 \%$ dijelaskan oleh variabel lain yang tidak diteliti dalam penelitian ini.

\section{KESIMPULAN}

Berdasarkan pembahasan dan pengujian-pengujian yang dilakukan, dapat di simpulkan bahwa Kualitas Pelayanan berpengaruh positif dan signifikan terhadap Minat Kunjungan Ulang pada Klinik Bidan Marlina. Hal ini menandakan bahwa pasien atau masyarakat banyak yang melakukan kunjungan ulang karena Kualitas Pelayanan yang baik dari klinik tersebut. Kualitas Pelayanan tersebut dapat dirasakan oleh pengunjung atau pasien mulai dari sebelum mereka datang, hingga mereka beranjak pulang. Adapun bentuknya antara lain; kemudahan mendapatkan pelayanan berupa informasi mengenai jenis pelayanan, jam kerja dokter, pengurusan administrasi, perawatan yang ramah, tanggap serta profesional dari perawat maupun dokter jaga, hingga keamanan dan kenyamanan suasana klinik itu sendiri. Selanjutnya untuk Brand Image juga berpengaruh positif dan signifikan terhadap Minat Kunjungan Ulang pada Klinik Bidan Marlina, artinya Citra Merek klinik terbentuk dengan baik sehingga memiliki reputasi yang baik. Mulai dari Citra pemilik, pengguna hingga citra produknya itu sendiri. Hal tersebut yang menyebabkan masyarakat atau pasien memutuskan untuk selalu melakukan kunjungan ulang jika mereka membutuhkannya. Hasil penelitian juga menyatakan terdapat pengaruh yang positif dan signifikan antara variabel bebas Kualitas Pelayanan dan Brand Image secara bersama-sama terhadap Minat Kunjungan Ulang. Artinya kualitas pelayanan yang dilakukan oleh Klinik Bidan Marlina dan Brand Image yang selama ini terbentuk, secara bersama-sama mempengaruhi terhadap kunjungan ulang pasien.
Saran yang dapat diberikan dalam penelitian ini adalah Kualitas Pelayanan yang dilakukan oleh Klinik Bidan Marlina sudah cukup baik, namun untuk dapat lebih meningkatkan minat kunjungan ulang para pasien, manajemen Klinik Bidan Marlina perlu meningkatkan kualitas pelayanan secara terus menerus. Adapun salah satu caranya dengan tidak segan memberikan pelatihan kepada para SDM agar mampu memberikan layanan yang ramah dan memuaskan kepada para pasiennya. Manajemen Klinik Bidan Marlina perlu mencari cara untuk mempertahankan Brand Image yang sudah terbentuk dengan baik, seperti melakukan kegiatan kehumasan dan marketing yang dapat memperkuat Brand Image. Untuk penelitian mendatang disarankan agar mengikutsertakan variabel-variabel lain yang diduga berpengaruh terhadap minat kunjungan ulang, seperti harga. Selain itu dapat juga menggunakan alat analisa lain seperti Structural Equation Models (SEM) untuk memverifikasi hasil penelitian.

\section{REFERENSI}

Ghozali, I. (2006). Aplikasi Analisis Multivariate Dengan Program SPSS. Cetakan Keempat. Semarang: Badan Penerbit Universitas Diponegoro.

Hair, J. F., JR, Anderson, R. E., Tatham, R. L., \& Black, W. C. (1998). Multivariate Data Analysis, Fifth Edition (Fifth Edit). New Jersey: Prentice Hall, Inc.

Lupiyoadi, H. (2006). Manajemen Pemasaran Jasa, Edisi Kedua. Jakarta: Salemba Empat.

Mahdani. (2009). Pengaruh Kualitas Pelayanan Terhadap Keputusan Kunjungan Ulang Pasien Rawat Jalan Pada Rumah Sakit Umum Daerah Sigli. Universitas Sumatera Utara.

Oliver, R. L. (1997). A Behavioral Perspective On The Consumer. New York: McGraw Hill Companies, Inc.

Parasuraman, A., Zeithhaml, V. A., \& L Berry, L. (1998). A Multiple Item Scale for Measuring Customer Perseption on Future Research. Journal of Marketing, 49, 1.

Sanusi, A. (2011). Metodologi Penelitian Bisnis. Jakarta: Salemba Empat.

Setiadi, N. J. (2008). Perilaku Konsumen Konsep dan Implikasi untuk Strategi dan Penelitian Pemasaran Edisi 1 Cetakan ke-3. Jakarta: Kencana Prenada Group.

Shimp, T. A. (2010). Advertising, Promotion, and Other Aspect of Intergrated Marketing Communications (8th editio). South-Western Cengage Learning, USA.

Solihin, I. (2004). Kamus Pemasaran. Cetakan Pertama. Bandung: Penerbit Pustaka.

Sugiyono. (2012). Metode Penelitian Kuantitatif 
Kualitatif dan $R \& B$. Bandung: Alfabeta.

Tasunar, N. (2006). Kualitas Layanan Sebagai Strategi Menciptakan Kepuasan pada Pangkalan Pendaratan Ikan (PPI) Morodemak. Jurnal Sains Pemasaran Indonesia, V, 41-62.

Tjiptono, F. (2012). Service Management Mewujudkan Layanan Prima. Yogyakarta: CV Andi Offset.

Tjiptono, F., \& Chandra, G. (2011). Service, Quality and Satisfaction. Yogyakarta: CV Andi. https://doi.org/10.3389/fgene.2015.00293

Umar, H. (2003). Sumber Daya Manusia Dalam Organisasi, Edisi revisi. Jakarta: PT Gramedia Pustaka Utama.

Xian, G. L., Xia, W., \& Yu, J. C. (2011). Corporate, Product and User Image Dimensions and Purchase Intentions. Journal of Computers, 6(No. 9), 1875-1879.

\section{PROFIL PENULIS}

Harun Al Rasyid, Pendidikan S1 Ilmu Komunikasi (S.Sos) Universitas Budi Luhur Jakarta, lulus tahun 2005. S2 Ilmu Manajemen (MM) Universitas BSI Bandung, lulus tahun 2016. Mengajar di Bina Sarana Informatika dari tahun 2008 hingga sekarang.

Agus Tri Indah K, Memperoleh gelar Sarjana Ilmu Sosial dan Ilmu Politik (S.IP) jurusan Administrasi Pemerintahan Universitas Gadjah Mada Yogyakarta, lulus Tahun 1995. Memperoleh gelar Magister Managemen (MM) Program Pasca Sarjana Universitas BSI Bandung, lulus tahun 2012. Mulai mengajar di Bina Sarana Informatika dari tahun 1999 sampai sekarang menjadi dosen di ASM BSI Jakarta. 